\title{
War in Afghanistan: Europe and America, between Films and Documentaries. 1979-2014
}

\author{
José Maurício Saldanha-Álvarez ${ }^{1}$ \\ ${ }^{1}$ Department of Media and Cultural Studies. Instituto de Arte e Comunicacao Social, Univrsidde Federl \\ Fluminense, Niterói, Brazil \\ Correspondence: José Maurício Saldanha-Álvarez, Department of Media and Cultural Studies. Instituto de Arte e \\ Comunicacao Social, Univrsidde Federl Fluminense, Niterói, Brazil. E-mail: saldanhaalvarez@hotmail.com
}

Received: November 22, 2016

Accepted: January 10, 2017

Online Published: February 28, 2017

doi:10.5539/ach.v9n1p26

URL: http://dx.doi.org/10.5539/ach.v9n1p26

\begin{abstract}
This research looks at the Afghanistan War from the Soviet invasion of 1979 until the withdrawal of North Atlantic Treaty Organization in 2014 through films chosen. This research demonstrates how the Soviets, supported by the USA and the Muslim world, operated on misconceptions during an insurrectional conflict against the Mujahedin. After September 11, the Bush-Cheney administration invaded Afghanistan, restricting the informative role of the corporate media system. According to Kellner, this action triggered a creative revolution in American cinema. Turning to the production of documentaries, directors abandoned large-scale productions, preferring highly dramatically charged narratives of real soldiers and real action. The Afghan war, a fragmented, relentless, and unremitting struggle, is portrayed in 9th Company (Rus), Restrepo (USA). And Armadillo (Denmark); and Kajaki (UK), films that narrates the conflict from the NATO perspective, can not be won.
\end{abstract}

Keywords: cinema, Afghanistan, war, documentaries, Taliban

\section{Introduction}

The post-9/11 scenario in the United States led the Bush-Cheney administration to restrict critics and media information about the conflicts, turning documentaries by the American film industry into a concrete alternative source of information and radical media (Downing, 2011). The documentary became a genre of unique complicity, providing an unrelenting and intimate look at the war movements, given that, according to Deleuze, the documentary originates from the world's memory (Deleuze, 1983).

Douglas Kellner believes that the Bush-Cheney administration was one of the most turbulent eras in American history. From the cinematic point of view, however, he believes that there was a renaissance in Hollywood that coincided with the expansion of films, whether intended to support (directly or indirectly) the war efforts or to inform the public and criticize the Bush-Cheney government (Kellner, 2010).

For the French researcher of strategic studies, Jean Michel Valantin, ever since the 1990s, big movie productions were made in the United States, combining the techniques of the big studios and the objectives of the Bush-Cheney administration. Mobilizing millions of dollars, this partnership produced "national security" films, images that equipped the military and civilian sectors for their internal efforts to justify the war in Afghanistan and in Iraq (Valantin, 2003). These works were the tools in the fight for the political representation of the nation's images and were presented to the media, universities and broad sectors of civil society (Valantin, 2003).

Nevertheless, as the United States is a democratic power, its power faces a counter-power (Valantin, 2003), expressed in the documentaries and responding to the need to inform a segment of the North American population about the conflict, thus creating alternative views in the political debate.

The Al Qaeda attack on America and the preparation of the Bush-Cheney administration for the media conflicts have consolidated the restriction of public access to information. Other external counter-powers against the country included the Arabic communication networks, such as the Al-Jazeera network, that showed the conflict from a different angle. As well, the British BBC provided trustworthy information to the American troops fighting in Iraq (Knightley, 2004).

The major American networks are information highways for communication disclosing excellent information and entertainment, but are also instruments of power. Despite all their power, they bowed before the false conscience 
of the Bush-Cheney administration, becoming obedient tools of the Pentagon and CENTCOM, according to Qatar (Holloway). The difficulty in obtaining trustworthy and true information, which the population eagerly desired, triggered this creative period in North American movies (Kellner, 2010).

\section{Method}

\subsection{Documentaries, Movies and the Struggle for Information}

American cinema has a consolidated and respected tradition in the production of documentaries and political films. In the majority of countries, the ease and objectivity of these productions would be unthinkable. Moviemakers such as Michael Moore, who produced works like Fahrenheit 9/11, filled the gaps of information left by the big media conglomerates that abstained from playing a critical role after September 11.

The documentary is the forerunner of other non-fictional genres that make up what we call sober discussions (Nichols, 1991, 3), allowing it to be a direct link to reality. For Nichols, the documentary as a concept or a practice is not covered by a fixed territory. If, on the one hand, the documentary is a space to share a vision, it is also a challenge for contestation. (Nichols, 1991).

Let's take a look at films of fiction and documentaries. Fiction movies are based on facts emerging beyond real-time military actions. Such films use actors instead of soldiers. Instead of the battlefield where the confrontation took place, a similar scenario is used, requiring the investment of vast resources in the complex productions of the movie industry.

However, all films of the genre, whether documentary or fictional, employ intertextuality in the form of cinematographic palimpsest between the two (Riffaterre, 1993).

The documentaries shaping the original text from which they seem to have been drawn were made by the French filmmaker Pierre Schoendoerffer. The first was Platoon 317 (1964), based on his own award-winning novel about the war of Indochina (1945-1954), as he had been imprisoned himself in Dien Bien Phu. Despite its use of professional actors, the film keeps a documental pace, a process made possible due to the director's intensive experience as documentarist for the French Army.

The second film was made a few years later (1967), during the American war in Vietnam when Schoendoerffer returned to Indochina and produced the documentary Anderson Platoon. With his narration of the diegesis of an American infantry platoon searching for the Viet Cong, in real-time action, it was awarded the Oscar for Best Documentary in 1968 (Macdonald, 2015).

In both films, Schoendoerffer launched a photographic look in dramatic black and white to capture the men, their actions and the setting in a stunning anthropologic sequence in the face of death (Nichols, 991).

For Paul Virilio, if great war films portray the rational significance of the conflict, documentaries draw their power from the resulting chaos of human actions unleashed on the battleground (Virilio, 2000).

In order to examine the rationality of the Afghan struggle and the chaos of the war on the scale of small units, we shall analyze two documentaries, the first one being the Danish Armadillo (2010) the second the North-American Restrepo (2010).

Next, we shall look at films of fiction that proposed to mediate the passage from reality to the fictional universe, such as the British Kajaki and the Russian 9th Company. Concentrating on the actions of small units such as squads, sections or companies, the films achieve great dramatic depth by portraying life on the battlefield of cohesive groups, where individuals know each other and whose composition, according to the French lieutenant colonel Michel Goya, enable such groups to perform complex tasks (Goya, 2014).

\section{Finds: Archeological Background}

\section{1 The Soviet War}

The involvement of the Soviet Union in Afghanistan started in 1978, when the country's president, Daoud Khan, was assassinated by the Marxist leader Mohammed Nur Taraki, who was backed by Moscow (Alexiev 1988). Nevertheless, the modernizing reforms undertaken by the Communist Party of Afghanistan endangered the traditional rural Afghan community, causing the population to rise up against the Kabul government, who began to lose control over the country.

In order to support its allies and maintain the course of the reforms, the Union of Soviet Socialist Republics invaded the country in 1979 without first studying the theater of operations. Years later, during Glasnost, the Soviet high command, was strongly criticized for not opposing the invasion (Liakhoski, 2007), its administration had not properly assessed the ability of the Islamic fighters. By opposing the invasion and modern reforms, it 
demonstrated its complete lack of realism when initiating a war that victimized more than one million persons and led to the dissidence of its Muslim republics (Gat, 2006).

When it invaded Afghanistan in 1979, the Soviet Union was facing a grave structural crisis, having to eliminate the centralized socialist system implemented in 1917 if it were to reach technological and economic parity with the West (Reuveny \& Prakash, 1999). The system's inefficiency and inflexibility could not satisfy the requirements of its status as a military superpower. Its economy was in decline and the country appeared technologically deficient (Hobsbawm, 1994).

For Charles Tilly, the Cold War and the intervention in Afghanistan were extremely costly conflicts for the USSR, disintegrating the foundations of the State and corroding the prestige of its armed forces (Tilly, 1993).

On the Afghan battlefield, the military command was surprised by the mobility of the Mujahedeen, dubbed doushkas by Soviet soldiers, or the invisibles (Cooley, 2000). The Afghan resistance was made up of around 60 guerilla organizations which received arms worth millions of dollars, provided to them when the recently elected president Ronald Reagan decided to defeat the USSR in the region (Bacevich, 2009). The Sting missile enabled the Mujahedeen to deprive the Soviets of the use of their fighter aircraft (Alexeyev, 1988). The use of this weapon took down more than 118 Soviet jets and 333 helicopters (Fremont-Barnes, 2012).

At the beginning of the invasion, the Soviet command kept to its doctrinal rigidity, but when it was faced with the irregularity of the war, it slowly changed its tactics, even though its troops, confined to the safety of their armored vehicles, were ambushed on the mountainous roads. (Richardson, 2009). To compensate for their low mobility, they employed Special Forces (Spetsnaz), paratroopers and an insufficient number of mountain troops. They intensified the use of combat helicopters and delegated more power to their junior officers commanding companies and squadrons. All these activities, however, proved incapable to beat the insurgence (Fremont-Barnes, 2012).

The operating troops suffered as a result of the precarious logistics, living undernourished and forced to steal food and be exposed by adopting the civilian way of life. In the movie 9th Company, one of the young soldiers is almost kidnapped and killed when entering an Afghan village looking for a box of matches in exchange for some object or other.

An important tactical innovation is featured in the film 9th Company, represented by Bonegruppa, a combat team consisting of tanks, VBTT, surrounded by infantry dispersed along the convoy. The Soviet command, in their desperation due to their inability to exterminate the invisible enemy, initiates a brutal repressive political maneuver against the civilian population, before quickly realizing there was no victory in sight, the insurrection being an endless drain of troops and equipment (Duran, 2013).

\subsection{The American War in Afghanistan}

The American invasion was a response to the 2001 September 11 attacks in New York, an episode that the French philosopher Wunenburger defined as "the prototype event of the new era of planetary communication" (Alvarez, 2004). Since Osama bin Laden lived in Afghanistan, the Taliban government refused to hand him over to the United States to be tried for the September 11 attacks (Cooley, 2000). We must keep in mind that for the Muslim world, Afghanistan was the country that heroically defeated the great atheist superpower in an epic struggle (Cooley, 2000).

The U.S. Secretary of Defense, Donald Rumsfeld, when planning the invasion of Afghanistan, ordered the general, Tommy Franks, to organize an immediate invasion plan that favored the use of the Special Forces.

Between October and December 2001, the Afghanistan Operation Enduring Freedom was unleashed, with British support. The Taliban forces and the Arab forces of Al-Qaeda scattered before the massive air attacks, keeping their offensive capabilities intact, taking refuge along the porous tribal border between Afghanistan and Pakistan.

From 2002 on, preparations for the invasion of Iraq led to a reflux of American military forces in Afghanistan, because, in the Bush-Cheney administration, Saddam Hussein was the next target. With the election of Hamid Karzai, the Coalition organized a government designed to stabilize the country, initiating a slow process of economic growth (Hersh, 2004). In rural areas, the landscape was discouraging; uncertainty was widespread due to the increase of gangsterism blocking the humanitarian agencies and reconstruction works, as can be seen in Restrepo and Kajaki. In 2008 there were 180 groups of criminals, consisting of about 120,000 men (Cavanna, 2015).

In spite of these efforts, the Taliban insurgence intensified to such an extent in 2009 that the commander of the Western troops in Afghanistan declared that, without significant changes, the war could be lost within a year. Meanwhile, the North American generals expressed their wish to employ forty thousand men on the ground, 
because as the war progressed, it would favor the Taliban, who expected that Western losses would cause them to win in the end (Hakimi, 2009).

\subsection{Europe against the Taliban: the Arrival of NATO}

On December 20, 2001, authorized by the United Nations Security Council, the NATO troops formed the International Security Assistance Force (ISAF) operating in Afghanistan, which included members of the Canadian, German, Dutch, Polish, Turkish, Italian, Norwegian, Latvian, Bulgarian, and Georgian forces.

This time, the Taliban did not have the modern and abundant equipment provided by the North American government during the war against the USSR. The Mujahedeen, using the old hit-and-run tactics, kept NATO in a permanent state of alertness. In small groups, they would ambush the posts and the troops, mining the roads with IEDs, leading offensives in many provinces (Hersh, 2004). The battle continued without any end in sight to the conflict until the suspension of NATO military operations in December 2014. However, in December 2015, British troops returned hastily to the province of Helkand to aid the embattled Afghan national army (Afghanistan Taliban, 2016).

\section{Results}

\subsection{Armadillo}

Directed by the Danish film-maker Janus Metz Pedersen, Armadillo was launched at the 2010 Cannes Festival and applauded by specialized critics. The Danish troops deployed to Afghanistan are an elite unit of the Royal Guard and in official ceremonies wear uniforms from the 19th century. During boarding, the soldiers' family members show great preoccupation about the future of the sons through anxious looks and gestures. The young men, on the contrary, finding themselves between worry and pride, consider their mission pure adventure.

A few critics, such as Kevin Macdonald, claim that the film is extremely well made: "In fact, one of the main criticism of Janus Metz Pedersen's Armadillo is that it is extremely well made: the poetic quality, color nuances and music of movies, supposedly mark this film as inauthentic" (Macdonald, 2015).

Mads, a young soldier nicknamed Mini, pilots an armed vehicle using high technology and remote control gunfire support. The tension on Mads' face is visible, his ability to maneuver the arms inside the vehicle is essential for the success of the patrol and for the protection of the lives of his companions.

The Mujahideen circulate freely in the neighborhoods of Armadillo. They shoot against the base and bomb it and it is impossible to distinguish them from the inhabitants of the miserly village, other than for their weapons. With repeated ambushes, this fanatical enemy is invisible, and just like in the Soviet War, they unsettle the European combatants. Under fire, the bodies of Danish soldiers show the chemical change produced by the danger. Attacked, the small unit retaliates the fire, jesting and crawling, loaded with equipment, looking for the protection of the big mud walls of the village.

The violence of war surprises the public and the Danish soldiers whose vehicle was blown up by an IED. The dead are veiled in a simultaneous Viking and Lutheran ceremony, lit by the fire and a large crucifix. To teach the Mujahideen a lesson, the Danish command dispatches a combat patrol to ambush their invisible enemy. After a fierce battle, the patrol liquidates some three or four Mujahideen, sheltered inside an irrigation channel. Euphoric, the soldiers discover the corpses of their elusive enemies. They are humble and tattered bodies, undernourished when compared to the burly Danes. The weapons of the dead are a scrawny war trophy; they are old worn-out Soviet weapons. The returning procession of the soldiers rather resembles a funeral, than a festive celebration.

\subsection{Restrepo}

This is a documentary (2010) directed by Tim Hetherington and Sebastian Junger showing the North American soldiers, members of Company 503rd of the Infantry Regiment, deployed to a post in the Korengal River Valley. He narrates the 15 months of daily activities of the men who stayed there, including their implementation of new units, who live in constant crossfire with the Taliban. The rugged, mountainous landscape of the Korengal Valley is an open road through which men, equipment and reinforcement move daily, coming from Pakistan. This traffic between the tribal areas of this porous frontier was a battleground in the Soviet War.

The opening scene shows a group of soldiers newly arrived from America, one of them, the soldier Restrepo of Colombian origin, travelling with his companions in a military Hummer that is hit by an IED and suddenly explodes, killing Restrepo.

This improvised weapon is the weapon of the poor, typical of the country. The French lieutenant Hugues Raoul, during his stay in Afghanistan, has written a diary about this deadly artifact. He and the officer who replaced him, inspected together the favorite places of the Taliban to plant them, "on the same day that we started to discover the IEDs and became victims of their lethal attacks" such as the one that took Restrepo's life. (Goya, 2014). 
A scene of an overflight by helicopter shows the magnificent, wild landscape of the Korengal, filled with densely wooded areas, ravines and caves. The young captain commanding the detachment remembers the warning of his commander: get ready; you will have at least five gunfires daily.

At the outpost, everyday life is to keep the weapons in readiness while living side by side with the population that does not distinguish itself from the enemy. The platoon would build a new station on a site used by the Taliban as a base for firing and mobilization. It would be called Restrepo. The men strive to work quickly so they would avoid being used as targets by the Taliban. The visit from a senior officer leads the captain to explain the exposed position occupied by the Americans and those of the invisible enemy in the Korengal sector.

A patrol is moving between the houses and the walled-up buildings, stopping at an attic to speak to a young Afghan through an interpreter who tries to obtain information. He refuses: "How can I speak about the Taliban and stay alive?" Chasing their invisible enemies, the American soldiers launch an operation called Rock Avalanche. Officers and soldiers are placed in front of a huge sandbox showing the valley, their routes and the suspected areas. The camera captures those that would be injured and the tragedy of someone who would die. The operation begins with helicopters and the use of heavy artillery. In the middle of the operation, a sergeant we had seen the previous day at the briefing is dead. One of his comrades, when receiving the news is in disbelief, crying convulsively at the loss of his companion, while the others try to comfort him in front of the merciless camera. It is, perhaps, the climax of the war portrayed in the film.

\subsection{The 9th Company}

This 2005 Russian movie is directed by Fyodor Bondarchuk, who also plays the role of a subordinate officer, in command of a unit that, at the end of the movie, defends a hill to its last man, without realizing that the war was over.

The Soviet soldiers and officers give up their rigid behavior in face of the reality of the insurrection. They become indistinguishable among themselves, wearing custom uniforms, breaking the rigid communist discipline. Food is so scarce that the combat troop must get it from the local population or steal it from the convoys. Bondarchuk does not show any use of drugs, even though their consumption would be a pervasive tactic at the final phase of the conflict.

The palimpsest process and the playback of other films are shown in the scene where the trendy hair of the recruits is shaved off with a reference to the opening scene of Full Metal Jacket, by Stanley Kubrick. After that, the recruits are taken to the training camps in Tajikistan, where they are instructed by a veteran sergeant. In their modest accommodations, routine inspection, humiliation and corporal punishment remind us of the movie Young Lions, by Edward Dmytryk (1958) and, again, Full Metal Jacket.

The merciless training shows a tough and emotional Soviet instructor, contrasting with the haughtiness portrayal by the actor Lee Ermey in Full Metal Jacket. The Russian instructor weeps when he must say goodbye to his pupils, while Lee Ermey's character remains tough until his death.

The 9th Company lands in Kabul, its arrival reminds us of the opening scene of Platoon, by Oliver Stone. The novices are welcomed by veterans who return to the "Soviet continent". One of them gives a talisman that protected him to a new arrival, saying that he no longer needs the object. However, the aircraft he boarded to the USSR is shot down by a Sting missile and the veteran, without the protection of the Talisman, dies.

At the end of the film, the final attack is unleashed by 250 Mujahideen whose contingents are reduced. The strategic hill in the 9th Company is assaulted and the remaining besieged are rescued by the arrival of armed helicopters that chase away the enemy. The return to the USSR is a depressing journey due to the meaninglessness of the Afghan war.

\subsection{Kajaki}

Kajaki (2014), a film by Paul Katsis, had its script written based on interviews with the surviving soldiers. This true story tells of a tragic episode lived through by the men of the 3rd Battalion of the 3rd Regiment of Paratroopers when, in September 2006, a patrol of this unit was guarding a reservation called Kajaki, located in the province of Helmand, against sabotage and infiltration by the Taliban.

The film begins when "Tug", the film's hero, is at leisure on the reservoir, while reinforcement is brought in by helicopter, depicted as a premonition of the tragedy that would ensue. At the rough and poor outpost (contrasting with the military riches shown in Armadillo and Restrepo), the communication equipment is not very safe. With simple and almost ragged clothes, the British expose their bodies to the sun. Some elusive contacts with the local population serve to lend the movie a touch of black humor (Pulver, 2015).

One of the soldiers reads the Barrack-Room Ballads by Rudyard Kipling, a popular cheap edition by Penguin Books, published in 1892. A poem therein is a tragic warning: "When you're wounded and left on Afghanistan's 
plains/ And the women come out to cut up what remains/ Just roll to your rifle and blow out your brains/ An' go to your Gawd like a soldier (Kipling, 1982)."

When feeding a dog missing one leg (blown up by a mine) a soldier reminds his comrade about the danger of this artifact. There are approximately 10 million Soviet mines spread throughout Afghanistan and the post of Kajaki is located at the place of an old Soviet outpost surrounded by an unmapped, anti-personnel minefield.

From the post, they can see the audacious Taliban extorting a gas station and charging toll on a road before the parachutists. After a failed air attack the night before, a patrol of three men gets out to inspect the invisible enemies. At their arrival to the site, one of the men steps on a mine that mutilates his leg. Helped by colleagues, he would only be rescued nine hours later by an Apache helicopter

Unlike the United States, where government resources are invested in films of war, the director, Paul Katsis, when filming the Afghan landscape in Jordan, requested the British Ministry of Defense the loan of an aircraft. In response, he received a peremptory refusal by the authorities citing budgetary restrictions. At that point, Katsis resorted to an excellent digitization to render the dogmatizing Chinooks and the Apaches in the film. The Paras, after overcoming the setbacks of communication, see the first helicopter, a giant Chinook, arriving to look after the injured, but because it would not fit through the narrow ravine, its powerful rotor exposes the mines that would blow up, injuring more soldiers. Eight men remain on the ground, moaning, struggling and comforting one another, while being rescued by their paramedic, Paul "Tug" Hartley, awaiting the arrival of the rescue.

Kajaki respects the wish of the paratroopers and does not describe them as infatuated heroes, but for professional soldiers, death is, as the French lieutenant-coronel Michel Goya said, a working hypothesis. For the Daily Telegraph journalist, they were a "Band of Brothers" because an elite regiment similar to the 3rd Paras, acts faster than the rest of the army (Goya, 2014). Identified by the emblems and badges of an elite force, the members often take risks beyond duty.

\section{Conclusion}

Movies as a discursive process have shown that the films conduct dialogues between themselves, and the documentary is a discourse of information and of battles. Since the Afghan war was fought by small and cohesive units, the films produced as a discursive process, represent this at a reduced but profoundly human scale. Instead of big combat units, the actions are reduced to a familiar group. The result is more dramatic films, whether documentaries or fictional productions supported by the big studios. The movie industry shows that Afghanistan seems to have resisted invaders for the past thirty years. Their invisible warriors are still active in the mountains. The Soviet invasion of Afghanistan was a failed attempt to modernize a Muslim agricultural country by an idealist state with Communist limitations. In Tariq Ali's opinion, the Taliban are orphans of the anti-Soviet war, the Mujahideen (Ali, 2002). All Western interventions in the country, since the overthrown Afghan monarchy in 1973, caused traumas and perplexities, suggesting the production of documentaries and films concentrating on and intensifying a war without a front, whose adversary seems phantasmagorical on the battlefield and on the screens of the combat monitors.

\section{References}

Alexeiev, A. (1988). The United States and the War in Afghanistan. Santa Monica: RAND Corporation.

Ali, T. (2002). The Clash of Fundamentalisms: Crusades, Jihads and Modernity. London: Verso.

Alvarez, J. M. S. (2004). O pênis bifurcado de Satan. Arte, imagem e cinema. Um ensaio sobre o 11 de setembro. (The bifurcated pênis of Satan. Art, image, and film. An essay on the September 11). Rio de Janeiro: Booklink.

Bacevich, A. (2009). The Limits of power. The end of the American exceptionalism. New York: Henry Holt \& Company.

BBC News. (2015). Afghanistan Taliban: British Military Deployed to Helmand. BBC, 22 Dec 2015. BBC News Web. 10 January, 2016.

Bondarchuk, F. (Director). (2005). 9th Company [Motion picture]. Perf. Artur Smolyaninov, Aleksey Chadov, Konstantin Kryukov. Gemini Film.

Cavanna, T. P. (2015). Hubris, Self-Interest, and America's Failed War in Afghanistan. The Self-Sustained Overreach. Lanham: Lexington Books.

Cooley, J. K. (2000). Unholy Wars: Afghanistan, America and International Terrorism. London: Pluto Press.

Deleuze, G. (1983). Cinéma I: L'Image-Mouvement. Paris: Éditions du Minuit.

Dmytryck, E. (Director). (1958). The Young Lions. Moction Picture. Perf. Marlon Brando, Dean Martin, Montgomery Clift, Barbara Hush, May Britt, Maximillian Schell. Twentieth Century Fox. 
Downing, J. D. H. (2001). Radical Media: Rebellion Communication and Social Movements. Thousand Oaks: Sage.

Duran, D. (2013). The Great Game and the Quagmire: Military adaptation in the British and Soviet War in Afghanistan. 1835-1989. In T. Farrel, F. Osinga, \& J. A. Russek (Eds.), Military adaptation in Afghanistan. Stanford: Stanford University Press.

Fremont-Barnes, G. (2012). The Soviet Afghan War 1979-89. Oxford: Osprey Publishing.

Gat, A. (2006). War in Human Civilization. Oxford: Oxford University Press.

Goya, M. (2014). Sous le Feu: La Mort Comme Hipothése de Travail. Paris: Tallandier.

Hakimi, A. (2009). Replacing the Strategy of War through Peace. Afghanistan, 1979-2009: In the Grip of the Conflict. A Special Edition of Viewpoints. Washington D.C.: Middle East Institute, Print.

Hersh, S. M. (2004). Chain of Command: The Road from 9/11 to Abu Ghraib. New York: Harper Collins.

Hetherington, T., \& Junger, S. (Directors). (2010). Restrepo. National Geographic Entertainment.

Hobsbawn, E. (1994). Age of extremes. The short twentieth century. Michael Joseph, London.

Holloway, D. (2009). 9/11 and the War on Terror. Edinburgh: Edinburgh University Press.

Katis, P. (Director). (2014). Kajaki [Motion picture]. Alchemy, 2014.

Kellner, D. (2010). Cinema Wars. Hollywood Film and Politics in the Bush-Cheney Era. Oxford: Wiley-Blackwell.

Kipling, R. (1982). Barrack-Room Ballads ( $4^{\text {th }}$ Ed.). London: Methuen.

Knightley, P. (2004). The First casuality. The War correspondent as hero and Myth-maker from the Crimea to Iraq. Baltimore \& London: Johns Hopkins University Press.

Kubrick, Stanley. (Director). (1987). Full Metal Jacket.

Liakhoskii, A. A. (2007). Inside the soviet invasion of Afghanistan and the seizure of Kabul, December 1979. Washington D C: Woodrow Wilson International Center for Scholars.

Macdonald, K. (2015). In the Firing Line: A Grunt's Eye View of War. The Guardian. 4 Apr. 2011. Web. 2 Dec.

Moore, M. (Director). (2004). Fahrenheit, 9/11 [Moction Picture].

Nichols, B. (1991). Representing Reality: Issues and Concepts in Documentary. Bloomington: Indiana University Press.

Paul, K. (Director). (2014). Kajaki. The True History. Pukka Films.

Pedersen. J. M. (Director). (2010). Armadillo. Moction Picture, Norsk Filmdistribusjon.

Pulver, A. (2015). "Why is Hollywood's take on the Afghan conflict so different from the UK's?" The Guardian. 20 Nov. 2014. Web. 10 December.

Reuveny, R., \& Prakash, A. (1999). The Afghan War and the Breakdown of the Soviet Union. London: Review of international Studies.

Richardson, B. G. (2009). Afghanistan “Treaty Bands”. Washington D. C.: Afghanistan, 1979-2009: In the Grip of Conflict. The Middle East Institute.

Riffaterre, M. (1993). Fictional Truth. Baltimore \& London: The Johns Hopkins University Press.

Schoendoerffer, P. (Director). (1964). The 317th Platoon. Perf. Jacques Perrin, Bruno Cremer. Rank.

Schoendoerffer, P. (Director). (1968). .Anderson Platoon, Perf. LT. Joseph B. Anderson. VHS, Format NTSC.

Tilly, C. (1993). European Revolutions. 1492-1992. Oxford: Blackwell.

Valantin, J. M. (2003). Hollywood, Le Pentagone et Washington: Les Trois Acteurs d'une Strategie Globale. Paris: Éditions Autrement, Print.

Virilio, P. (2000). The Strategy of Deception. Trans. Chris Turner. London: Verso.

\section{Copyrights}

Copyright for this article is retained by the author(s), with first publication rights granted to the journal.

This is an open-access article distributed under the terms and conditions of the Creative Commons Attribution license (http://creativecommons.org/licenses/by/4.0/). 